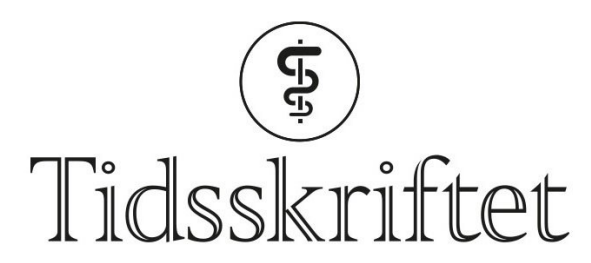

DEN NORSKE LEGEFORENING

\title{
Har du en plan?
}

MINILEDER

ARE BREAN

Sjefredaktør

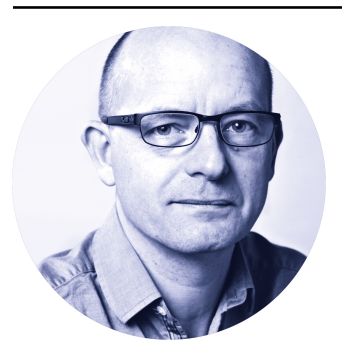

"Jeg har en plan», sa Egon Olsen, og 1970-årenes kinogjengere visste at nå ble det gøy. En plan er fint å ha, ikke bare for den perfekte forbrytelse, men også dersom du skal i gang med et forskningsprosjekt. Fra og med 1. juli 2018 må du ikke bare planlegge hvordan du skal samle og analysere dataene i prosjektet. Du må også ha en datadelingsplan.

I 2017 publiserte International Committee on Publication Ethics (ICMJE) retningslinjer for hvilke krav vitenskapelige tidsskrifter skal stille for deling av forskningsdata: Manuskripter som bygger på data fra kliniske studier, skal ledsages av en beskrivelse av hvilke muligheter andre har til å få tilgang til data på individnivå. Dette vil også gjelde i Tidsskriftet. Foreløpig er det ingen plikt til å dele. Nei er et greit svar, så lenge det kan begrunnes. For data kan selvsagt bare deles dersom pasienten har samtykket til det, og lovverk og infrastruktur er på plass.

Fortsatt gjenstår det mye før deling av individbaserte, sensitive helseopplysninger kan gjennomføres på en bred skala. Kravet om en datadelingsplan er et forsiktig steg, i riktig retning, mot en mer etterrettelig og åpen vitenskap.

Publisert: 12. juni 2018. Tidsskr Nor Legeforen. DOI: 10.4045/tidsskr.18.10.01

(C) Tidsskrift for Den norske legeforening 2020. Lastet ned fra tidsskriftet.no 